\title{
(POST-)DEUTERONOMISTYCZNY ZAKAZ TRANSWESTYTYZMU (PWT 22,5)? PYTANIE O JEGO WŁAŚCIWY SENS I MOTYWACJĘ
}

O tym, jaki jest „typowy” strój kobiecy lub męski, decydują uwarunkowania geograficzne, historyczne i społeczne. Wystarczy porównać pod tym względem ,typowe” stroje męskie i kobiece w Europie i Chinach, a nawet w samej Europie, mając na uwadze tradycyjny strój Szkotów czy starożytne stroje Greków i Rzymian. Płciowy charakter danego stroju definiuje zatem dana społeczność, a decyduje o tym jej kultura oraz historia. Przy czym każda społeczność ma pod tym względem własną gender ideology. Bez niej strój sam w sobie nie ma jeszcze ściśle określonego znaczenia. Przypisuje mu je dopiero nadana mu społecznie funkcja. Niewątpliwie stanowi on wizualizację ciała i osobowości. Ma to potem także społeczne odniesienia zarówno ze strony noszącego, jak i patrzącego. ${ }^{1}$

Przez transwestytyzm zwykle rozumie się dziś jakiś rodzaj zaburzenia, polegającego na upodobaniu do przebierania się w stroje płci przeciwnej w celu osiągniecia satysfakcji emocjonalnej (transwestytyzm podwójnej roli) lub seksualnej (transwestytyzm fetyszystyczny). W Biblii Hebrajskiej - jak się wydaje - znajdujemy tylko jedno prawo zakazujące tak rozumianego transwestytyzmu i, jak potem wynika z badań, może to być jedyne tego typu prawo nie tylko w samej Biblii, ale i na całym starożytnym Bliskim Wschodzie. ${ }^{2}$

1 J. H. Walton, J. H. Walton, The Lost World of the Torah: Law as Covenant in Ancient Context, IVP Academic, Downer Grove 2019, s. 186.

2 P. J. Harland, Menswear and Womenswear: A Study of Deuteronomy 22:5, Expository Times 110/ 1998-1999, s. 73-76. 
Spór o to, czego i dlaczego w istocie ono jednak zakazuje, trwa do dziś. Bo choć słowo „transwestytyzm” (łac. trans - „za”, ,poza”, „po drugiej stronie”; vestitus - „ubranie”) jest dość niedawne (pojawiło się w 1910 r.), to problemy współcześnie nim opisywane znane są od dawna. Niemniej aktualne określenie i rozumienie tych zjawisk nie musi odzwierciedlać rzeczywistych intencji autora biblijnego. W kontekście współczesnej kultury, kiedy zmienia się nie tylko moda i przypisane przez tradycję wzorce ubierania się „typowe” dla kobiet i mężczyzn, ale i pojawiają się też nowe konteksty dla szeroko rozumianego transwestytyzmu, warto spojrzeć na wspomniany zakaz z Pwt 22,5 raz jeszcze. A to dlatego, że czasem zbyt dosłowne rozumienie, nie zawsze najlepszego możliwego tłumaczenia, może prowadzić do nazbyt literalnej interpretacji i zagubienia istoty oraz ducha samego tekstu.

\section{Problem}

Prawo, którym chcemy się zająć, ma charakter apodyktyczny i brzmi następująco:

lō'-jihjeh kelî-geber 'al-'iššāh

welō'-jilbbaš geber śimlat 'iššăh

kî tô 'ăbat JHWH 'ělōhejkā kōl-'ôséh 'ēlleh (Pwt 22,5).

Spójrzmy na kilka współczesnych, polskich tłumaczeń:

„Kobieta nie będzie nosiła ubrania mężczyzny i nie włoży mężczyzna szaty kobiecej, gdyż obrzydliwością dla Pana, twego Boga, jest każdy, kto to czyni” (Biblia Ekumeniczna).

„Kobiety niech nie noszą odzienia męskiego, a mężczyźni niech się nie ubierają w suknie kobiece. Kto by czynił inaczej, będzie budził odrazę w waszym Bogu Jahwe" (Biblia Warszawsko-Praska). 
„Kobieta nie będzie nosiła ubioru mężczyzny, ani mężczyzna ubioru kobiety, gdyż każdy, kto tak postępuje, obrzydły jest dla Pana, Boga swego" (Biblia Tysiąclecia, wyd. VB).

„Kobieta nie może wkładać na siebie ubrania mężczyzny, ani mężczyzna ubierać się w strój kobiety, bo kto by czynił podobne rzeczy, będzie wstrętny dla Pana, twojego Boga" (Biblia św. Pawła).

„Kobieta nie przywdzieje ubrania mężczyzny, mężczyzna zaś nie przywdzieje szat kobiety, gdyż wstrętnym są dla twego Boga, Jahwe, ci wszyscy, którzy tak czynią" (Biblia Poznańska).

„Nie będzie nosiła kobieta ubrania męskiego, ani nie będzie wdziewał sukni kobiecej mężczyzna, gdyż kto tak postępuje, obrzydły jest dla Jahwe, swego Boga" (S. Łach).

„Nie będzie ubioru na kobiecie, i nie ubierze mąż szaty kobiety, gdyż obrzydliwością (dla) JHWH, Boga twojego, każdy (kto) czyni te (rzeczy)" (Przekład interlinearny; A. Kuśmirek).

Wszystkie powyższe tłumaczenia, jak łatwo zauważyć, oddają zwrot kelî-geber w sensie „ubranie”, „ubiór”, „odzienie mężczyzny”. Takie rozumienie tego zwrotu sugeruje jego paralelność z drugą częścią wiersza, w której zwrot śimlat 'iššs̄ah bez wątpienia oznacza strój kobiety, gdyż śimlat to: „wierzchnia garderoba”, „płaszcz”, „osłona”, czyli najogólniej mówiąc „,garderoba, ubranie”3 choć także „narzuta” np. na łóżko (Rdz 9,23; Pwt 22,17). Jedynie Anna Kuśmirek wyraża pewną dozę niepewności, pomijając w zwrocie kelî-geber tłumaczenie drugiego wyrazu. Zabieg ten i proponowany przez nią sposób tłumaczenia sprawia jednak, że w efekcie samo tłumaczenie wygląda bardziej na dziwne niż ostrożne.

3 KBL, t. II, s. 360. 
Rzecz w tym, że wspomniany zwrot kelî-geber zawiera dwie niewiadome. Pierwsze słowo (kelî) ma szerszy i tym samym mniej precyzyjny sens niż tylko „ubranie”, a drugie (geber) z kolei odwrotnie, bardzo precyzyjnie określa mężczyznę, akcentując właśnie jego „męskość”, czym bardziej wzmacnia zamierzony kontrast „mężczyzna - kobieta" (geber -'iššāh), niż gdyby prawodawca zastosował dla przykładu zestawienie 'î̌s-'iššāh. W związku z tym wielu egzegetów i tłumaczy słusznie stawia sobie pytanie o precyzyjny sens całego zwrotu, gdyż wybór prawodawcy wydaje się tu dobrze przemyślany. Został zapewne dokonany po to, by nie tyle zakazać jakiejkolwiek zmiany stroju przypisywanego w konkretnej kulturze tej lub innej płci, ile transwestytyzmu w określonych sytuacjach. ${ }^{4}$ Intencją tego przepisu, najogólniej rzecz ujmując, jest zakaz przekraczania pewnych granic. O jakie granice jednak dokładnie chodzi? W jakim kontekście należy szukać odniesień dla tego ograniczenia? Pytaniu o właściwy sens towarzyszy zatem kolejne: Co ów precyzyjny sens oznacza w kontekście formuły quazi-motywacyjnej, ${ }^{5}$ jaką jest ocena zakazanych czynności jako tô ‘ăbat JHWH?

4 Jednak patrząc na ikonografię, nie można mieć wątpliwości, że czasy biblijne miały swoje standardy odnośnie do strojów męskich i kobiecych; por. H. Weippert, Kleidung, w: M. Görg, B. Lang (red.), Neues Bibel-Lexikon, t. 2, Benziger, Zürich-Düsseldorf 1995, s. 495-499, tenże, Kleidung, w: K. Galling (red.), Biblische Reallexikon, HAT Erste Reihe, Mohr-Siebeck, Tübingen 1977, s. 185-188. W języku polskim por. rozdział Ubiór i kosmetyki, w: J. I. Packer, M. C. Tenney (red.), Słownik tła Biblii, tłum. Z. Kościuk, „Vocatio”, Warszawa 2007, s. 401-413.

5 Gerhard von Rad nazywa to uzasadnienie „tautologią teologiczną”, a nie prawdziwym uzasadnieniem. Formuła wskazuje na coś, co w żaden sposób nie da się pogodzić z kultem Jhwh. W opinii von Rada teksty opatrzone taką „,tautologiczną" motywacją $(17,1 ; 22,5 ; 23,19 ; 25,16)$ mogły kiedyś nawet tworzyć pewien osobny zbiór przepisów liturgicznych; G. von Rad, Teologia Starego Testamentu, tłum. B. Widła, Instytut Wydawniczy Pax, Warszawa 1986, s. 160 i przyp. 21.

${ }_{6}$ W miarę pełny przegląd aktualnego stanu dyskusji oprócz przywoływanych tu komentarzy (zwł. J. R. Lundbom, E. Otto) znaleźć można również w artykule N. S. Fox, Gender Transformation and Transgression: Contextualizing the Prohibition of Cross-Dressing in Deuteronomy 22:5, w: N. S. Fox, D. A. Glatt-Gilad, M. J. Williams (red.), Mishneh Todah. Studies in Deuteronomy and Its Cultural 
Obu tym kwestiom chcemy przyjrzeć się bliżej. Najpierw przeanalizujemy kontekst literacki badanej wypowiedzi i status quaestionis w zakresie badań natury krytyczno-literackiej. Następnie przeanalizujemy alternatywne w stosunku do cytowanych powyżej możliwości egzegetycznej i translatorskiej interpretacji hebrajskiego oryginału. W końcu przebadamy proponowane przez egzegetów okoliczności, które mogły spowodować sformułowanie tego apodyktycznego zakazu z Pwt 22,5.

\section{Kontekst literacki}

Perykopa, do którego przynależy interesujący nas przepis, to w sumie zarazem minizbiór praw. Bywa ona zatem różnie limitowana. Trudno ją bowiem jednoznacznie klasyfikować ze względu na tematykę. W szerszym kontekście można dostrzec większą całość (Pwt 19,1 - 22,8), której granice wyznacza temat winy za przelaną krew $(19,10 ; 22,8$ : dāmîm). Przy węższym spojrzeniu, mamy tu zbiór prawa rodzinnego (Pwt 22,13-21.22-29), różne prawa natury społecznej (Pwt 22,1-4.6-8) i zakazy dotyczące mieszania gatunków (Pwt 22,5.9-11). Bezpośredni kontekst dla badanej wypowiedzi stanowiłaby tu zatem perykopa z Pwt 22,1-8 lub Pwt 22,1-12. W pierwszym przypadku chodzi jednak o dość luźno powiązane ze sobą prawa „zawieszone” na różnych odsłonach przykazania „nie zabijaj” (ww. 6-7.8). We wspomnianym minizbiorze tej kwestii dotykają jednak jedynie ostatnie dwa prawa. ${ }^{7}$ Tylko w nich można bowiem doszukać się rozwinięcia tematu ,nie zabijaj”. Jedno stanowi protekcję samicy ptaka, która ma młode pisklęta $(22,6-7)$, a drugie ma

Environment. Fs. J. H. Tigay, Eisenbrauns, Winona Lake 2009, s. 49-71; C. L. Crouch, The Making of Israel: Cultural Diversity in the Southern Levant, Brill, Leiden-Boston 2014, s. 155-157; H. Lipka, The Prohibition of Cross-Dressing. What does Deuteronomy 22: 5 Prohibit and Why? thetorach.com (dostęp: 10 VI 2019).

7 Por. jednak S. A. Kaufman, The Structure of the Deuteronomic Law, Maarav 12/1978-1979, s. 136. Badacz ten sugeruje, że w. 5, podobnie jak przepis z ww. 6-7, dotyczy tematu śmierci (łączy je idea oddzielenia: mężczyzna i kobieta; matka i jej młode). Autor bardziej jednak tego domniemywa, niż przekonująco udowadnia. 
na uwadze możliwość nieumyślnej winy za śmierć z powodu niezabezpieczenia nowo zbudowanego dachu $(22,8)$. Pozostałe prawa nie mają już nic wspólnego z tematem śmierci i są ze sobą dość luźno powiązane (w. 1-3: zwrot utraconej własności; w. 4: kwestia zwierzęcia, które upadło; w. 5: zakaz transwestytyzmu). Egzegeci wykazują jednak liczne, drobne związki lingwistyczne, które łączą ze sobą poszczególne przepisy z tego zbioru. ${ }^{8}$ Tematyczne Pwt 22,5 łączy się jednak dopiero z przepisami z Pwt 22,9-11, a biorąc pod uwagę temat „ubrania”, także z w. 12. Z tego powodu obecne usytuowanie kontekstualne (między ww. 1-4 i ww. 6-8) jest dość zaskakujące. Strukturalnie sposób sformułowania zakazu z w. 5 (trzecia osoba liczby pojedynczej zastosowana w podwójnej formule) ma swoje odpowiedniki w Pwt 23,18; 24,16.

\section{Krytyka literacka}

Gustav Hölscher ${ }^{9}$ pisał swego czasu, że „wraz z rozdziałem 22 każde sensowne uporządkowanie prawa się kończy". Badacz ten także, jako jeden z pierwszych, wskazywał, że Pwt 22,1-4.6-7 stanowi część tzw. Ur-Deuteronomium, zaś Pwt 22,5.9-12 to późniejszy dodatek. Carl Steuernagel ${ }^{10}$ całość Pwt 22,1-23,1 klasyfikował jako materiał dodany wtórnie do zasadniczego korpusu księgi. Przegląd kolejnych propozycji wskazuje, że te dwie opinie, z różnymi wariantami, były podzielane przez kolejnych badaczy. ${ }^{11}$ Patrząc na poruszane tu kwestie, Pwt 22,1-4 można odnieść do przepisów z Wj 23,4-5

8 A. Rofé, The Arangement of the Laws in Deteronomy, w: tenże, Deuteronomy. Issues and Interpretation, T\&T Clark, London-New York 2002, s. 62, 72; J. R. Lundbom, Deuteronomy. A Commentary, Eerdmans, Cambridge 2013, s. 613. W szerszym wymiarze (22,1-12) por. E. Otto, Deuteronomium 12,1-23,15, HThKAT, Herder, Freiburg-Basel-Wien 2016, s. 1676.

9 G. Hölscher, Kompostion und Ursprungs der Deuteronomiums, Zeitschrift für die alttestamentlische Wissenschaft 40/1922, s. 209.

10 C. Steuernagel, Das Deuteronomium übersetzt und erklärt, HK I 3/1, Vandenhoeck\& Ruprecht, Göttingen $1923^{2}$, s. 131-135.

11 E. Otto, Deuteronomium 12,1-23,15, s. 1681-1684. 
i potraktować jako ich rozwinięcie lub dopowiedzenie do wcześniejszej wersji z Kodeksu Przymierza. Pwt 22,9-11 natomiast wyraźnie stanowi nawiązanie do Kpł 19,19 i z dużym prawdopodobieństwem jest późniejsze niż ten fragment Kodeksu Świętości, choć - jak chcą inni - mogło być też odwrotnie i to autor Kodeksu Świętości miał przed oczami zarówno Kodeks Przymierza, jak i Kodeks Deuteronomistyczny. ${ }^{12}$ Pwt 22,5, czyli przepis, który chcemy zbadać, tematycznie, jak wspomnieliśmy, łączy się z kwestią niemieszania odmiennych gatunków poruszaną w Pwt 22,9-11.

Trzeba jednak zauważyć, że nie do końca traktuje się w obu przypadkach o tym samym. ${ }^{13} \mathrm{Z}$ w. 12 z kolei, przez temat ubrania, łączy się w. 5. Słuszne wydaje się więc pytanie o to, czemu zatem w. 5 nie znajduje się bezpośrednio we właściwym sobie kontekście? Samo jego ulokowanie między Pwt 22,1-4.6-8 wydaje się wtórne, jak zauważał to choćby wspomniany już Hölscher. Czy zatem w. 5 jest też wtórny w całym tym zbiorze? Może tak być, choć nie można wykluczyć także, że pierwsza jego część (w. 5ab) jest nieco wcześniejsza (por. przywoływane już formuły z Pwt 23,18 i 24,16) i została jedynie uzupełniona później o zdanie motywacyjne z w. 5c. ${ }^{14}$ Jeśli jednak w istocie przepis z Pwt 22,5 jest powygnaniowym Fortschreibung, ${ }^{15}$ to przy interpretacji intersującego nas przepisu należy mieć na uwadze przede wszystkim kontekst całego Pięcioksięgu.

12 Tak tamże, s. 1686.

13 Jak pisze Eugene H. Merrill, Pwt 22,5 to ,a regulation that seems most intrusive in the overall passage"; E.H. Merrill, Deuteronomy, NAC 4, B\&H Publishing Group, Nashville 1994, s. 297.

14 Tak sugerują m. in. A. D. H. Mayes, Deuteronomy, NCBC, Eerdmans, Grand Rapids 1981², s. 307; E. Nielsen, Deuteronomium, HAT 1/6, Mohr-Siebeck, Tübingen 1995, s. 214.

15 Tak E. Otto, Deuteronomium 12,1 - 23,15, s. 1697-1698, wcześniej też P. J. Harland, Menswear and Womenswear, s. 73-76. 


\section{Szerokie możliwości egzegetyczne}

Pierwsze i zasadnicze pytanie brzmi: Czy mając na uwadze paralelny układ w. 5aA i w. 5aB, możemy być pewni, że kelî-geber oznacza to samo, co śimlat 'iššāh , czyli odpowiednio „strój mężczyzny” i „strój kobiety"? Patrząc już choćby pobieżnie na znaczenie słów kelî i śimlat, odpowiedź musi brzmieć: nie! Przyjrzyjmy się zatem bliżej poszczególnym słowom, które decydują o właściwym sensie całej wypowiedzi.

\section{geber}

Bez wątpienia, obok zwrotu tô ăbat JHWH, jest to kluczowe słowo pozwalające zrozumieć właściwy sens całego zakazu. W w. 5aAB pojawia się aż dwa razy, na zasadzie antonimu, w zestawieniu z określeniem kobiety jako ’iššăh. Chodzi zatem o sens „mężczyzna - kobieta'. Czemu jednak prawodawca nie użył zestawienia: 'î̌s -'iššāh (w sensie: mąż - żona; por. Pwt 22,13)? Zastosowanie słowa geber wydaje się tu jednak dobrze przemyślane. Rzeczownik pochodzi od rdzenia czasownikowego gbr - ,być silnym”, ,przeważać”16 $\mathrm{i}$ - co najistotniejsze - nie ma swego żeńskiego odpowiednika. ${ }^{17} \mathrm{~W}$ przypadku słowa 'î̌s, poza istnieniem żeńskiego odpowiednika, warto zwrócić uwagę także na fakt, że może być ono używane również w sensie neutralnym: „,człowiek”, „ludzie”, „osoba” (por. Wj 35,21). ${ }^{18}$ Podobnie rzecz się ma z innymi potencjalnymi słowami, którymi można by próbować wyrazić sens „mężczyzna” ('ādām, 'ěnôš). Rzeczownik

$16 \mathrm{Ges}^{18}$, t. 1, Springer-Verlag, Berlin 1987, s. 197: forma podstawowa, środkowohebrajska, jako sens podstawowy ma oprócz znaczenia ogólnego „mężczyzna”, również: „kogut”, ,penis”.

17 Słowo gebîrâ (por. KBL, t. 1, s. 164), choć pochodzi od tego samego rdzenia, nie jest mimo wszystko żeńskim odpowiednikiem dla słowa geber, gdyż ma zupełnie odmienny od niego zakres znaczeń semantycznych. Podkreśla bardziej pozycję społeczną niż kobiecość; por. H. Kosmala, gabar, w: TDOT, t. 2, Eerdmans, Grand Rapids 1977, s. 367-382, zwł. s. 373; V.P. Hamilton, gebîrâ, w: NIDOTTE, t. 1, Paternoster Press, London 1997, s. 800-802

18 N. P. Bratsiotis, 'î̌s, w: TDOT, t. 1, Eerdmans, Grand Rapids 1977, s. 222-235. 
geber w stosunku do wszystkich tych słów wyróżnia fakt, że zawsze oznacza on wyłącznie dorosłego mężczyznę (wyjątek to Hi 3,3). Co więcej, słowo to akcentuje w sposób szczególny ową „męskość": odwagę, męstwo, hart ducha (Ps 127,5; Hi 38,3). W tym sensie każdy mężczyzna jest ' $\hat{\imath} \grave{s}$, ale nie każdy jest geber. Nie jest to ta sama forma intensywności, jaką ma pochodzący od tego samego rdzenia rzeczownik gibbôr, jednak jasne jest, że nie można go rozumieć także jako zwykłe tylko określenie „mężczyzna”. ${ }^{19}$ Czasem używa się go jako synonim słowa $z \bar{a} k \bar{a} r$ - „mężczyzna”, „osobnik płci męskiej” $(\mathrm{Rdz} 1,27 ; 5,2 ; 6,19 ; 7,2),{ }^{20}$ jednak ten ma swój antonim w postaci słowa negabāh ( $\mathrm{Rdz} 1,27$; Jr 31,22). ${ }^{21}$ Zatem prawodawca wybierając słowo geber, miał na uwadze szczególny charakter męskości i chciał uwydatnić go w opozycji do kobiecości. ${ }^{22}$

\section{kelî}

Rzeczownik ten ma bardzo szeroki wachlarz znaczeń. Opisuje się nim najpierw różne typy pojemników, bagaży i urządzeń. Potem może oznaczać narzędzia, broń, a nawet zbroję. W dalszej kolejności za jego pomocą opisuje się wyposażenie wnętrz, meble i rozmaite inne domowe sprzęty. Wreszcie oznacza on również biżuterię i ozdoby, a nawet instrumenty muzyczne. ${ }^{23}$ Chcąc uogólnić jego

19 H. Kosmala, gabar, s. 377-378.

20 KBL, t. 1, s. 258.

21 Na temat obu słów por. J. Lemański, Księga Rodzaju rozdziały 1-11, NKB. ST I/1, Św. Paweł, Częstochowa 2013, s. 169.

22 Na temat precyzyjnego znaczenia wszystkich wymienionych słów i wyrażanych przez nie aspektów por. M. Zvi Brettler, Gender in the Bible, w: A. Berlin, M. Zvi Brettler (red.), Jewish Study Bible, Oxford University Press, New York 2014, s. 2177-2184. Potem również M. Zvi Brettler, ,Happy is the man, who fills his quiver with them" (Ps 127,5): Construction of Masculinities in the Psalms, w: I. Zsolnay (red.), Being a Man: Negatiating Ancient Constructs of Masculinity, Studies in the History of the Ancient Near East, Routledge, London 2017, s. 198-203.

23 K. M. Beyse, kelî, w: TDOT, t. 7, Eerdmans, Grand Rapids 1995, s. 169-175; DCH, t. 4, s. 420-424. Dla Pwt 22,5 w: KBL, t. 1, s. 452; DCH, t. 4, s. 424 sugerowany jest sens: „ubiór męski”. 
znaczenie, możemy stwierdzić, że opisuje się nim jakąś osobistą własność. Targum Pseudo-Jonatana proponuje, by w. 5aA rozumieć jako rytualne męskie stroje (tefillim - filakterie i tzit-tzit - rytualne, niebieskie frędzle). Interpretacja ta wiązała się jednak z dyskutowanym znacznie później problemem, czy kobiety mogą nosić tego rodzaju rytualne stroje. Ze względu na połączenie ze słowem geber, w późniejszej egzegezie rabinicznej pojawiły się także propozycje, by w Pwt 22,5a widzieć zakaz noszenia zbroi lub broni przez kobiety (Rabbi Eliezer ben Jaakow: Sifre Debarim § 226; b.Nazir 59a). Jak zauważyliśmy, taki sens słowa kelî nie jest rzadkością w Biblii Hebrajskiej (Pwt 1,41; Sdz 18,11; 1Sm 8,12; $2 \mathrm{Krl} \mathrm{11,8;} \mathrm{Jr} \mathrm{21,4).}{ }^{24}$ Jednak tłumacz Septuaginty stosuje w tym przypadku greckie słowo skeue, o równie szerokim wachlarzu znaczeń, co tłumaczone nim hebrajskie kelî. Grecki odpowiednik może bowiem oznaczać ubiór, ubranie, kostium, odzież, szatę, jak również styl, modę, uzbrojenie, a w liczbie mnogiej nawet przybory okrętowe. ${ }^{25}$

Mimo to, w połączeniu z intencjonalnie wybranym rzeczownikiem geber, słowo kelî może jednak oznaczać jakiś specyficzny przedmiot należący wyłącznie, albo przynajmniej w sposób szczególny, do mężczyzny: broń (Pwt 1,41) choć i równie dobrze jakiś inny, mniej „męski” przedmiot (Pwt 23,25: kosz?). ${ }^{26}$

24 K. M. Beyse, kelî, s. 172.

25 O. Jurewicz (oprac.), Słownik grecko-polski, Wydawnictwo Szkolne PWN, Warszawa 2001, s. 299. Dla Pwt 22,5 sugerowany jest sens ,ubranie” (ang. outfit); por. J. Lust, E. Eynikel, K. Hauspie, A Greek-English Lexicon of the Sepruagint, t. 2, Deutsche Bibelgesellschaft, Stuttgart 1996, s. 428. Potem także H. A. Hoffner jr., Symbols for Masculinity and Femininity: Their Use in Ancient Near Eastern Pathetic Magic Rituals, Journal of Biblical Literature 85/1966, s. 326-334, zw1. s. 332-333.

26 Richard D. Nelson wspomina nawet, że padła propozycja, by pod zwrotem tym rozumieć , an artificial phallus”. Nie udało mi się dotrzeć jednak do źródła tej propozycji, a sam Nelson nic nie cytuje; R. D. Nelson, Deuteronomy, OTL, John Knox Press, Louisville-London 2002, s. 264. Sens powinien być jednak chyba bardziej ogólny ,things pertaining to a man”; tak D. L. Christensen, Deuteronomy 21,10 - 34,12, WBC 6B, Thomas Nelson Publishing, Nashville 2002, s. 492. 


\section{Śimlat}

Najogólniej rzecz ujmując, słowem tym określa się coś, co przykrywa człowieka lub jakiś przedmiot (Rdz 9,23; Pwt 22,17). W liczbie mnogiej zwykle chodzi o ubranie, w tym także ubranie mężczyzny (Rdz 37,34; Wj 19,10; Joz 7,6). W takich przypadkach zwykle stosuje się, jak i tym razem, wraz z tym rzeczownikiem czasownik $l b \check{s}-$ „ubierać się”, „wkładać”. W obecnym przypadku sam rzeczownik jest doprecyzowany słowem 'išš $\bar{a} h$. Chodzi więc o wierzchnie ubranie kobiece i zakaz wkładania go przez mężczyzn (w. 5aB).

\section{tô $\breve{a} b a t J h w h$}

Termin tô'ébāh opisuje odrazę, obrzydzenie. ${ }^{27}$ Występuje dość często w Księdze Powtórzonego Prawa. ${ }^{28}$ Odnosi się tu do osób (Pwt 23,8; 25,16), praktyk (Pwt 24,4) i rzeczy (Pwt 12,31; 14,3). Dla Jhwh za tô 'ébāh uchodzą przede wszystkim idole (Pwt 7,25-26; 27,15; por. Jr 16,18) i ludzie uprawiający idolatrię (Pwt 13,13-15; 17,2-4). Czasem chodzi także o praktyki wróżbiarskie (Pwt 18,9-12). W swoim najstarszym zastosowaniu (Pwt 32,16), ${ }^{29}$ słowo to odnosi się do kultu obcych bogów. Termin ten stanowi zatem przede wszystkim uzasadnienie (motywację) o charakterze kultowym. W ten sposób określany jest potem również zakaz homoseksualizmu w Kpł 18,22. Natomiast w Księdze Powtórzonego Prawa „odrażający” dla Jhwh jest także ten, kto fałszuje miary i wagi (Pwt 25,13-16; por. Jr 6,15=8,12). Za odrażające uznaje się też niektóre pokarmy (Pwt 14,3), składanie niedoskonałych ofiar (Pwt 17,1) i analizowane tu zakładanie ubrań drugiej płci (Pwt 22,5).

27 KBL, t. 2, s. 639-640.

28 S. R. Driver, A Critical and Exegetical Commentary on Deuteronomy, ICC, T\&T Clark, Edinburg 1895, s. 1xxxiii, przyp. 70; M. Weinfeld, Deuteronomy and Deuteronomic School, Clarendon, Oxford 1972, s. 323, przyp. 1.1a.

29 Tamże. 
W zbiorze przysłów z okresu starobabilońskiego, znajdującym się na jednej ze szkolnych tabliczek odkrytych w Nippur, podobnym słowem kończy się cały ten zbiór. Dlatego William Hallo ${ }^{30}$ używa w stosunku do niego określenia punch-line. We wspomnianym tekście czytamy:
„Sędzia, który wypacza sprawiedliwość,
Przekleństwo, które spada na stronę mająca słuszność,
[pierworodny] dziedzic, który pozbawia młodszego [syna]
patrymonium
to są obrzydliwości Ninurty" [tłum. własne].

Inne powiedzenia z tego zbioru kończą się odwołaniem także do innych bóstw: „to są obrzydliwości Utu, (...) Suen, (...) Marduka”. Egipska instrukcja Amen-em-opet, ${ }^{31}$ przytaczana przez wspomnianego W. Hallo, także konkluduje niektóre powiedzenia słowami: „To jest obrzydliwością dla boga". Zatem w opinii tego badacza chodzi w tych wszystkich przypadkach, w tym także w Pwt 22,5b, o wpływy środowiska mądrościowego, zwłaszcza że podobne wypowiedzi znajdujemy także w biblijnej Księdze Przysłów (por. Prz 6,16-19).

Obecny przypadek (Pwt 22,5) Richard Nelson ${ }^{32}$ uznaje za jeden z wielu przykładów, gdy określenie tô ‘̆bat Jhwh zawiera echo bardziej technicznego zastosowania całego zwrotu, którego sens idzie dalej niż tylko kwestia nieczystości rytualnej (por. Pwt 14,3; 17,1; 18,12; 23,18-19; 24,14). Ta końcowa formuła pozwala nam więc podejrzewać, że zakaz sięga kwestii o wiele dalej idących niż tylko zwykła zamiana strojów właściwych odmiennej płci. ${ }^{33}$

30 W. W. Hallo, Biblical Abominations and Sumerian Taboos, Eisenbrauns 1985, 76/1985-1986, s. 21-40, zwł. s. 34, skąd pochodzi przytoczony cytat.

31 ANET $^{3}$, s. 423, rozdz. 10 i 13.

32 R. D. Nelson, Deuteronomy, s. 268.

33 Tak słusznie P. C. Craigie, The Book of Deuteronomy, NICOT, Eerdmans, Grand Rapids 1976, s. 287. 


\section{Potencjalne Sitz im Leben}

O ile dyskusja natury egzegetycznej może prowadzić do względnego konsensusu, że chodzi ogólnie o zakaz transwestytyzmu lub o zamianę typowych ról przypisanych określonej płci, to już okoliczności i odniesienia dla tego zakazu pozostawiają wiele niewiadomych. ${ }^{34}$ Sama formuła motywacyjna sugeruje jakieś kultowe odniesienia (por. Pwt 7,25). Jak zauważyliśmy jednak, w. 5 b może być wtórny, a wtedy w grę wchodzi wiele różnych możliwych motywacji dla wprowadzenia tego zakazu.

\section{Udział w wojnie}

Prekursorem tej interpretacji, popularnej - jak wspomnieliśmy wcześniej - w późniejszej egzegezie rabinackiej, był Józef Flawiusz. Pisał on: „Nade wszystko pilnujcie w bitwach tego, by nigdy niewiasta nie otrzymała ekwipunku mężczyzny ani mężczyzna nie przywdział szaty niewieściej" (Ant. IV.43.301). ${ }^{35}$

Rozumiał on zatem zwrot kelî-geber w sensie „ekwipunek mężczyzny", a całe prawo jako element zasad dotyczących stroju obowiązujących na wojnie (por. Sifre Debarim § 226). W podobnym tonie pisał zresztą w bliskich mu czasach także rzymski satyryk Juvenalis: „Quem praestare potest mulier galeata pudorum, quae fugit a sexu? Uires amat” (Sat. VI 252-253). ${ }^{36}$ "Cóż za wstydliwość może okazać kobieta nosząca hełm na głowie, która wyrzeka się swej płci? Kocha siłę" [tłum. własne].

Juvenalis myśli tu o kobiecie, która pasjonuje się współczesnymi mu sztukami walki, czyli sprawami typowo męskimi. Inspiracji do tego typu interpretacji zakazu z Pwt 22,5 szukano także

34 A. D. H. Mayes, Deuteronomy, s. 307; N. S. Fox, Gender, s. 49: „An odd duck-unique to biblical law and unique in the corpus of ancien Near Eastern literature".

35 Józef Flawiusz, Dawne dzieje Izraela, cz. 1, tłum. Z. Kubiak, J. Radożycki, Oficyna Wydawnicza Rytm, Warszawa 1997, s. 237.

36 Loeb Classical Library: loebclassics.com. 
we fragmencie ugaryckiego Eposu o Akhacie (KTU 1,19.iv.44-46). ${ }^{37}$ Tam bohaterka o imieniu Pughat, chcą pomścić śmierć brata, pod odzieniem kobiety (npṣa att) wkłada na siebie strój wojownika (npṣ ǵzr). Wierzchnie, kobiece, odzienie pomaga jej także ukryć sztylet i miecz. Przebranie ma ją upodobnić do bogini Anat.

Podobny do wymienionych powyżej kontekst dla Pwt 22,5 wskazuje również Harold Tolger Vedeler. ${ }^{38}$ Jego zdaniem specyfika zwrotu kelî-geber wskazuje, że nie chodzi w tym przepisie prawnym o zakaz wkładania przez kobiety męskiego stroju w ogóle, ale o akces kobiety do specyficznie męskich przyborów, wyrażających męską siłę i władzę także w wymiarze religijnym. ${ }^{39}$

W istocie, jak zauważyliśmy, zwrot kelî-geber może mieć sens broń (Pwt 1,41) lub wyposażenie typowe dla mężczyzny ( $\mathrm{Rdz} 27,3$ : przybory myśliwskie), zaś rzeczownik geber akcentować mocniej „męskość”, co dodatkowo wspiera rozumienie pierwszego członu w sensie „broń”. W tekście biblijnym jednak, ani kontekst, ani sposób sformułowania zakazu nie sugerują takiego zawężonego rozumienia tego przepisu.

37 C. H. Gordon, A Note on the Tenth Commandment, Journal of Bible and Religion 31/1963, s. 208-209. Polskie tłumaczenie tekstu w: A. Tronina, Eposy ugaryckie o Kerecie i Akhacie, w: A. Paciorek (red.), Scripturae Lumen. Biblia i jej oddziatywanie, t. 1: Ewangelia o Królestwie, Wydawnictwo KUL, Lublin 2009, s. 563-621, przywoływany fragment s. 616.

38 H. T. Vedeler, Reconstructing Meaning in Deuteronomy 22:5: Gender, Society, and Transvestitism in Israel and the Ancient Near East, Journal of Biblical Literature 127/2008, s. 459-476.

39 Tamże, s. 473. Zakaz ma na celu odsunięcie ,,all women from accessing a weapon or any other symbol of power not of men in general but of the most masculine and religious upright of men. The verse sets the $g b r$ nearly apart from women and the danger they represent". Chcąc podkreślić różnice między geber oraz ' $\imath \grave{s}$, Vedeler tłumaczy cały zwrot w sensie: „A woman shall not be associated with the instrument of a superior...". 
Nadużycia seksualne

Przebieranie się w ubrania płci przeciwnej może mieć na celu uwiedzenie kogoś lub stanowić identyfikację z określoną grupą nastawioną na uprawienie niedozwolonego seksu. Tylko wtedy jest ono zakazane, uważali rabini (b. Nazir 59a; Raszi). ${ }^{40}$ Wszelkie inne cele, np. świętowanie podczas Purim, są natomiast dozwolone (Szulhan Arukh, OH 69b:8). W Biblii Hebrajskiej ani poza nią nie znajdujemy jednak przykładów transwestytyzmu typu homoseksualnego, który chce widzieć w tle tego zakazu np. Calum M. Carmichael. ${ }^{41}$ Łączy on praktykę homoseksualizmu z przepisami dotyczącymi wojny z Pwt 20 i uważa, że chodzi o to, by kobiety nie przywdziewały zbroi, chcąc brać udział w walce (por. Pwt 3,19). Żaden z analizowanych przez niego tekstów nie mówi jednak wprost o homoseksualizmie. Nie ma zresztą nawet pewności, że Pwt 3,19 i 22,5 należy ze sobą łączyć pod względem tematycznym.

Wilfred G. Lambert ${ }^{42}$ cytuje jedno z przysłów z okresu Średniego Państwa Asyryjskiego, które wydaje się odzwierciedlać praktykę transwestytyzmu, jednak trudno jest odnieść je do jakiegoś konkretnego kontekstu: „...Pewien Amoryta rzekł [do] swej żony, ty będziesz mężczyzną, [ja] będę kobietą [odtąd]... stał się mężczyzna [...] kobiece [...] męskie".

Sam Lambert uważa jednak, że tego rodzaju praktyka po raz pierwszy zostaje potępiona właśnie w Pwt 22,5. Na pewno tego typu zachowania znane były i praktykowane w świecie klasycznym,

40 Bogatą i chyba pełną (pozycja była mi niedostępna) paletę odniesień do egzegezy rabinicznej znaleźć można w T. Liebman, The Jewish Exegetical History of Deuteronomy 22:5: Required Gender Separation or Prohibited Cross-Dressing? Masters Thesis, Departament of Jewish Studies, McGill University, Montreal 2002.

${ }_{41}$ C. M. Carmichael, The Law of Deuteronomy, Cornell University Press, Ithaca 1974, s. 147.

42 W. G. Lambert, Babylonian Wisdom Lterature, Clarendon, Oxford 1960, s. $126,226,230$. 
w Grecji, Azji Mniejszej i na terenach Syrii. ${ }^{43}$ Miały tu one jednak różne odniesienia i przede wszystkim chodzi o czasy późniejsze niż badany przez nas zakaz z Pwt 22,5. Wcześniejszych przykładów tego rodzaju zachowania jest niewiele. ${ }^{44}$ Jeśli jednak prawodawca ma na uwadze jakieś praktyki związane $\mathrm{z}$ homoseksualizmem, ${ }^{45}$ to zostały one odrzucone wraz z ogólnym zakazem praktykowania go w Izraelu (Kpł 18,22; 20,13). ${ }^{46}$ Nawet jeśli założymy, że wraca do tej kwestii w związku z zakazem mieszania gatunków (w tym przypadku strojów właściwych danej płci), to musimy pamięć, iż Stary Testament zna tylko homoseksualizm w wydaniu męskim, nie zawiera natomiast żadnych wskazań w kwestii kobiet. ${ }^{47}$ Zatem pierwsza część analizowanej prohibicji (w. 5aA) byłaby tu trudnym do uzasadnienia wyjątkiem.

\section{Idolatria i magia}

Zakaz pewnych rytualnych zachowań związanych z obcymi kultami, to częsty motyw przywoływany przez komentatorów. ${ }^{48}$

43 S. R. Driver, A Critical and Exegetical Commentary on Deuteronomy, s. 250; Th. H. Gaster, Myth, Legend, and Custom in the Old Testament, Harper \& Row, New York 1969, s. 316-317; H. Licht, Sexual Life in Ancient Greece, tłum. J. H. Freese, Constable, London 1994 (oryg. niem. z 1931), s. 124-125, 500; M. E. Doerfler, Coming Apart at the Seams: Cross-dressing Masculinity, and the Social Body in Late Antiquity, w: A. Batten, C. Daniel-Hughes, K. Upson-Saia (red.), Dressing Judeans and Christians in Antiquity, VT: Ashgate, Burlington 2014, s. 37-54.

44 N. S. Fox, Gender, s. 49-71.

45 Tak sugeruje m.in. E. Otto, Deuteronomium 12,1 - 23,15, s. 1698, wskazując na opinię J. Milgroma.

46 W. W. Hallo, Biblical Abominations, s. 37; H. T. Vedeler, Reconstructing Meaning in Deuteronomy 22:5, s. 468.

47 Na temat homoseksualizmu w Biblii Hebrajskiej por. I. i J. Slawik, Homoseksualizm problemem Kościoła? Rocznik Teologiczny 52/2010, s. 9-69; J. Lemański, Księga Rodzaju rozdziaty 11,27 - 36,43, NKB. ST I/1, Św. Paweł, Częstochowa 2014, s. 393-404.

48 Tak choćby G. Braulik, Deuteronomium II 16,18 - 34,1, NEB, Echter Verlag, Würzburg, 1992, s. 161-162; J. H. Tigay, Deuteronomy, JPS Torah Commentary, 
W istocie już Mojżesz Majmonides łączył zakaz z idolatrią (Przewodnik dla zakłopotanych 3:37). Badacze wielokrotnie podkreślali, że tego typu praktyki były znane w mezopotamskim kulcie Inany/ Isztar czy kananejskim kulcie Asztarte. ${ }^{49}$ Bogini ta miała pewne androgeniczne cechy, a więc reprezentowała coś, co było nieznane antropologii biblijnej - trzecią płeć (androgynia - hermafrodyta)..$^{50}$ Podobne cechy miała także być może syryjska bogini Anat. Sugeruje to fragment tekstu zachowany w języku egipskim. ${ }^{51}$ Porównywany jest on do ugaryckiego cyklu Anatu-Ba'alu. W przywołanym fragmencie tekstu bóstwo Re/El zwraca się do bogini w następujący sposób: „Co ci się stało Anatu, ty zwycięska kobieta, która jest jak mężczyzna, ubrana jak mężczyzna, a przepasana jak kobieta?”

Philadelphia Jewish Publication Society 1996, s. 200; C. S. Rodd, Glimpses of a Strange Land. Studies in Old Testament Ethics, T\&T Clark, Edinburg 2001, s. 11; S. Paganini, Deuteronomium, I libri Biblici. Primo Testamento, Paoline, Milano 2011, s. 329. Ze starszych egzegetów można wskazać na G. von Rad, Deuteronomio, thum. A. dal Bianco, Paidea Editrice, Brescia 1979, s. 157 (oryg. niem. 1964); S. Łach, Ksiega Powtórzonego Prawa, PŚST II-3, Pallotinum, Poznań-Warszawa 1971, s. 221; A. Penna, Deteronomio, Manetti, Torino-Roma 1976, s. 202; A. D. H Mayes, Deuteronomy, s. 307.

49 W. H. Ph. Römer, Randbemerkungen zur Travestie von Deut. 22.5, w: M. Heerm van Voss i in. (red.), Travestie in the World of the Old Testament, Studia Semitica Neerlandica 16, LVan Gorcum, Assen 1974, s. 217-222; W. W. Hallo, Biblical Abominations, s. 21-40.

${ }^{50}$ C. L. Crouch, The Making, s. 156. Potem także B. Groneberg, Die sumerisch-akkadische Inanna/Ištar: Hermaphroditas? Die Welt des Orients 17/1986, s. 25-46; R. Harris, Inanna-Istar as Paradox and a Coincidence of Opposites, History of Religion 30/1991, s. 261-278; toż, w: tenże (red.), Gender and Aging in Mesopotamia: The Gilgamesh Epic and Other Ancient Literature, University of Oklahoma Press, Norman 2000, s. 158-171; L. M. Pryke, Ishtar: Gods and Heroes of Ancient World, Routledge, London-New York 2017. W języku polskim por. hasło Inana/Isztar, w: J. Black, A. Green (red.), Słownik mitologii Mezopotamii, Księżnica, Katowice 1998, s. 86-89.

${ }^{51}$ E. Otto, Deuteronomium 12,1 - 23,15, s. 1698 cytuje go ze wskazaniem na W. Helck, Betrachtungen zur Grossen Göttinund der ihn verbundenen Gottheiten, Religion und Kultur der alten Mittelmeerwelt in Parallelforschungen, Oldenbourg, München-Wien 1971, s. 153. 
Cechy bogini Inany/Isztar/Anatu i specyfika związanego z nimi kultu przetrwały w późniejszym okresie w kulcie bogini Atargatis. ${ }^{52}$ Mogły być zatem znane w okresie powyganiowym w Judzie (por. 2Mch 12,26).

W mitologii i kulcie z Mezopotamii bogowie i boginie często zamieniali także swoje płciowe role. W okresie neobabilońskim Isztar określana jest w jednej z modlitw najpierw jako „lwica”, a zaraz potem jako „zajadły lew”. ${ }^{53}$ Także na hetyckim reliefie z modlitwą błagalną w czasie cierpienia, orant zwraca się do boga-słońca m.in. takimi słowami: „Ty, mój boże, jesteś dla mnie ojcem i matką” [tłum. własne]. ${ }^{54}$

„Zmienność płci” u bóstw mogła prowadzić zatem do kultu, w którym wyznawcy również usiłowali dostosować się do wyobrażeń o czczonym przez siebie bogu lub bogini. Dochodziło do tego, zwłaszcza gdy chodziło o boginię. ${ }^{55}$ Słynny tekst przypisywany Lucjanowi z Samosaty (De Dea Syria), ${ }^{56}$ opisuje praktyki związane z religią celebrowaną w Hieropolis (dawne Mabbûq), gdzie czczono boginię Rhea. Kapłan Galli, chcą poświecić się całkowicie czczonej przez siebie bogini, dokonał samokastracji, zaprzestał męskiego stylu życia i nosił kobiece stroje.

52 H. J. W. Drijvers, Atargatis, w: K. van der Toorn i in. (red.), Dictionary of Deities and Demons in the Bible, Brill, Leiden-Boston-Köln 1999, s. 114-116.

$53 \mathrm{ANET}^{3}$, s. 384 linie 31,51.

54 Tamże, s. 401.

55 W. Roscoe, Priest of the Goodess: Gender Transgression in Ancient Religion, History of Religion 35/1996, s. 213-217. Na ten temat także N. S. Fox, Gender, s. 52-53; H. T. Vedeler, Reconstructing Meaning in Deuteronomy 22:5, s. 464-469. Zwyczaj ten znany był nie tylko w Mezopotamii, ale praktykowany również w północnym Kanaanie, Transjordanii, Filistei, a nawet okolicach Beer Szeby, w dolinie Azal; por. R. Kletter, Pots and Polities: Material Remaine of Late Iron Age Judah in Relation to Its Political Border, Bulletin of the American Schools of Oriental Research 34/1999, s. 19-54, 381-385; N. S. Fox, Gender, s. 57-58, 61-62.

56 H. W. Attridge, R. A. Oden, The Syrian Goddess (De Dea Syria). Attributed to Lucian, Society of Biblical Literature. Texts and Translations 9, Scholars, Missoula 1976, s. 23, 37, 39, 55. 
Nie ma jednak dowodów na to, że taki kult tej sumeryjsko-babilońskiej bogini był praktykowany kiedykolwiek w Izraelu, ani tym bardziej że praktykowano zwyczaje, jak ten opisany przez Lucjana. Nawet jeśli założymy, że bezpośredni sąsiedzi Izraelitów znali takie praktyki, to i w tym przypadku ponownie brak dowodów, że Izraelici w nich uczestniczyli. Ponadto Deuteronomista krytykuje wprost wszelkie formy idolatrii (Pwt 12,29-31; 13,13-19; 17,2-7) i nie ma potrzeby uszczegółowiania w ten sposób jednej z nich.

Harry A. Hoffner ${ }^{57}$ sugeruje z kolei, że chodzi o zakaz pewnego rodzaju zachowań magicznych, znanych w Kanaanie i religii hetyckiej. Używane w tego rodzaju praktykach przedmioty symbolizowały męskość i bohaterstwo (łuk) lub kobiecość i płodność (spinki, lusterka). Chodziło generalnie o przebieranie się, by symbolicznie podkreślić męskość lub kobiecość, co - jak pisze Hoffner ${ }^{58}$ - miało na celu ,to maintain restore or eradicate the sexual potency of oneself or one's enemy'. W Izraelu znano również przekleństwa i złorzeczenia wobec nieprzyjaciół. Być może formuły werbalne także wzmacniano odpowiednimi rytuałami i przebraniami. Nie ma jednak wprost o tym mowy w Pwt 22,5, a sam zakaz jest na tyle ogólny, by zachować ostrożność w ocenie słuszności tego typu sugestii. ${ }^{59}$

\section{Porządek wyznaczony aktem stworzenia}

Ten aspekt szczególnie podkreślił Cornelius Houtman. ${ }^{60} \mathrm{~W}$ swoim czasie pisał już jednak o tym podobnie Filon z Aleksandrii (20 przed Chr. - 40/50?/ po Chr.):

Prawo wykazuje tak gorącą troskę o to, aby wyszkolić duszę i wyćwiczyć w męstwie, że nawet podaje wskazówki na temat ubrania, jakie należy nosić. Zakazuje wyraźnie mężczyźnie wkładać kobiece

\footnotetext{
57 A. Hoffner jr., Symbols for Masculinity and Femininity, s. 326-334.

58 Tamże, s. 334.

59 N. S. Fox, Gender, s. 68-69; E. Otto, Deuteronomium 12,1-23,15, s. 1697.

60 C. Houtman, Another Look at Forbidden Mixtures, Vetus Testamentum 34/1984, s. 226-228.
} 
ubrania, by nie było na nim śladu i cienia kobiecości ze szkodą dla jego męskiego charakteru. Prawo mianowicie trzyma się zawsze natury i chce określić odpowiednie i zgodne ze sobą reguły aż do najmniejszych szczegółów i rzeczy, które przez swą niepokaźność wydają się niewidoczne. Prawodawca wiedział, że kształty ciała mężczyzny i kobiety, podobnie jak się je widzi wykreślone na tablicy, nie są równe, i że dla obu rodzajów nie jest przeznaczone to samo życie, ponieważ jedna płeć jest przeznaczona do życia w domu, a druga do życia publicznego w państwie. I dlatego uznał za pożyteczne podać odpowiednie przepisy również w innych sprawach, które nie są wprawdzie określone przez naturę, ale, zgodnie z natura, są wymyślone przez zdrowy rozsądek. Są to przepisy dotyczące sposobu życia i ubrania, i podobnych rzeczy. Prawodawca uważał, że prawdziwy mężczyzna powinien zachować męski charakter, a w szczególności pod względem ubrania. W ubraniu, które zawsze nosi we dnie i w nocy, nie powinien przejawiać najmniejszego znaku świadczącego o braku męskości. W taki sam sposób prawodawca chciał przyzwyczaić kobiety do noszenia odpowiednich ozdób i zabronił im wkładać na siebie męski ubiór, ponieważ chciał usunąć zjawisko zniewieściałych mężczyzn, jak i kobiet o męskich cechach charakteru (Peri aretōn 18-20). ${ }^{61}$

Filon niewątpliwie odnosi się tu do dominującej w jego czasach kultury grecko-rzymskiej, w której każda płeć miała wyznaczoną sobie rolę społeczną. Przywołuje tu greckie pojęcie andreias - „męskość" i to na nim opiera cały sens zakazu z Pwt 22,5, do którego wyraźnie się odnosi. Ostatecznym punktem odniesienia jest dla niego nadany przez Stwórcę porządek natury. W ostatnim czasie, także ze względu na dominująca dziś powygnaniową datację tekstu, takie odniesienie zakazu z Pwt 22,5 zdobywa najwięcej zwolenników. ${ }^{62}$

61 Filon Alexandryjski, Pisma, tłum. L. Joachimowicz, Instytut Wydawniczy Pax, Warszawa 1986, s. 236.

62 Por. dyskusje i autorów cytowanych w: J. Goldingay, Old Testament Theology, t. 3: Israel's Life, IPV Academic, Dovners Grove 2009, s. 613. 
Pwt 22,5 wpisuje się w koncepcję, że należy żyć zgodnie z porządkiem ustanowionym aktem stworzenia, zachowując oddzielnie to, co zostało w nim w naturalny sposób rozdzielone i odróżnione (różne zwierzęta, zboża, materiały, ubrania właściwe odmiennej płci i rozróżnienie gatunkowe: człowiek - zwierzęta; por. Kpł 19,19; Pwt 22,5; 27,21). Księga Powtórzonego Prawa w ogólności zachowuje takie rozumienie porządku stworzenia i przez poszczególne przepisy wyraża wolę zachowania tego naturalnego rozróżnienia nadanego aktem stworzenia (por. Rdz 1,4.6-7.14.18). ${ }^{63}$

Mając to na uwadze, Tikva Frymer-Kensky ${ }^{64}$ zasadniczy motyw zakazu widzi w fakcie, że zacieranie choćby tylko symbolicznych granic pozwalających rozróżnić płeć stanowi naruszenie naturalnego podziału na mężczyzn i kobiety. Dwupłciowy podział natury ludzkiej opisany w Rdz 1-2, jako zasadniczy motyw dla obecnej prohibicji, jak i potępienia homoseksualizmu w szczególności, wskazują również Gordon J. Wenham ${ }^{65}$ i Peter J. Harland. ${ }^{66}$ Zwłaszcza drugi z tych badaczy wychodzi od założenia o powygnaniowym pochodzeniu zakazu z Pwt 22,5. Z tego względu odniesienie go do fundamentalnych rozstrzygnięć antropologicznych z Rdz 1-2 uważa za oczywiste. Zachowanie porządku stworzenia opisanego w Rdz 1 wskazuje on jako warunek decydujący o istnieniu Izraela jako ,świętego narodu”. ${ }^{67}$

W szerszym znaczeniu chodzi o zachowania stanowiące pogwałcenie lub zamazanie granic naturalnych i społecznych, co według przepisów z Kpł 19,19 (nie mieszać dwóch różnych gatunków; por. Pwt 22,9-11) może stanowić przyczynę zaciągnięcia nieczystości rytualnej. Mając więc na uwadze prawdopodobny powygnaniowy

63 A. D. H. Mayes, Deuteronomy, s. 306; P. D. Miller, Deuteronomy, John Knox, Louisville 1990, s. 162; M. E. Biddle, Deuteronomy, Smith\&Helwys, Macon 2003, s. 347.

64 T. Frymer-Kensky, Law and Philosophy: The Case of Sex in the Bible, Semeia 45/1989, s. 96-97.

65 G. J. Wenham, The Old Testament Attitude to Homoseksuality, Expository Times 102/1990-1991, s. 259-363.

66 P. J. Harland, Menswear and Womenswear, s. 76

${ }_{67}$ Tamże, s. 75-76. 
kontekst obecnego zakazu (Pwt 22,5), należy zatem uwzględnić w jego interpretacji - jak już o tym była mowa - kontekst całego Pięcioksięgu. W konsekwencji więc należy przyjąć, że prawodawca ma w tym przypadku na uwadze zarówno ogólnie rozumianą zasadę niemieszania gatunków, jak i charakterystyczny dla antropologii biblijnej dwupłciowy podział gatunku ludzkiego (Rdz 1,26-27; 2,7 25). W świecie biblijnym strój stanowi o identyfikacji danej osoby (por. 2Krl 2,13-14: płaszcz Eliasza; Rdz 37-50 stroje Józefa). ${ }^{68}$ Należy go zatem nosić/wkładać zgodnie z przyjętymi społecznie zasadami i miejscem zajmowanym w danej społeczności.

Wspominana już Nili Sacher Fox ${ }^{69}$ sądzi, że motywacją do wprowadzenia zakazu była sama struktura społeczności patriarchalnej, prowadzącej w większości rolniczy styl życia i zamieszkującej w większości niewielkie osady. Modelem podstawowym dla tego rodzaju społeczności był dwupłciowy podział na mężczyzn i kobiety. Czy jednak wtedy prawodawca potrzebowałby użyć aż tak specyficznego zwrotu, jak kelî-geber ${ }^{70}$ Patriarchalny trop w tym przypadku wydaje się dobry, ale sens jest chyba raczej taki, że przepis ma uchronić przede wszystkim to, co specyficznie męskie w ramach społeczności Izraela. Tak więc kobiety nie powinny sięgać po specyficznie męskie akcesoria (kelî-geber), a i mężczyźni w żaden sposób nie powinni ubierać się jak kobiety (feminizacja).

\section{$* * *$}

Przeanalizowany powyżej przepis z Pwt 22,5 ma charakter apodyktyczny. Składa się z dwóch paralelnych względem siebie zakazów oraz formuły quazi-motywacyjnej (tô ăbat JHWH), klasyfikującej go w kontekście Powtórzonego Prawa jako jedną z norm chroniącą zasady prawidłowego sprawowania kultu lub właściwego zachowania

68 E. Otto, Deuteronomium 12,1 - 23,15, s. 1698.

69 N. S. Fox, Gender, s. 49-71.

70 Dyskusja na ten temat zwłaszcza w: H. T. Vedeler, Reconstructing Meaning in Deuteronomy 22:5, s. 471-473. 
pozwalającego na udział w kulcie. Jeśli jednak cały przepis lub przynajmniej sama formuła motywacyjna z nim związana są powygnaniowe, jak chce dziś większość badaczy, to liczba możliwości interpretacyjnych w znaczący sposób maleje. Nie wiemy, jakie mogły być pierwotne uwarunkowania zakazu z dwuwiersza Pwt 22,5ab. Nie wiemy nawet, czy należy w ogóle doszukiwać się jakichkolwiek pierwotnego Sitz im Leben dla tego zakazu. Jeśli tak, to być może w istocie były to jakieś nieortodoksyjne w jahwizmie sposoby zachowań kultowych lub wręcz sprawowane w Izraelu obce kulty. Nie można jedna wykluczyć, że prawodawcy chodziło pierwotnie o zupełnie coś innego. W tej kwestii musimy pozostać w sferze spekulacji. Jeśli natomiast cały przepis, a nie tylko jego ostatnia część (w. 5c), jest sformułowany po wygnaniu, to zarówno sam zakaz, jak i towarzysząca mu formuła quazi-motywacyjna, mogą stanowić jedynie odniesienie do kontekstu, jakim jest cały Pięcioksiąg. Na pierwszy plan wysuwa się tu zatem antropologia biblijna z jej - jasno zarysowaną - dwupłciową strukturą człowieka, a zaraz potem porządek stworzenia, rozumiany jako gatunkowe i rodzajowe zróżnicowanie pośród stworzeń (Rdz 1-2; Kpł 19,19; Pwt 22,9-11). Za takim zrozumieniem tego przepisu przemawia jego „niewłaściwe” usytuowanie w kontekście. Choć tematycznie łączy się on z Pwt 22,9-11/12, to znajduje się jednak między Pwt 22,1-4.6-8. Jego aktualne miejsce w kontekście można zatem zrozumieć jako efekt późniejszego, przemyślanego glosowania. Czemu służyło jednak takie umiejscowienie? Być może temu, by podkreślić jeden z aspektów związanych z tematem ,zachowania życia" (por. ww. 6-8). ${ }^{71} \mathrm{~W}$ tym sensie utrata tożsamości płciowej prowadzić mogła do zaniechania zdolności prokreacyjnych (por. Rdz 1,28; 5,1-3; 9,1.7²). Z drugiej strony, taki kanoniczny sposób interpretacji tego przepisu nie wyczerpuje jednak, w mojej opinii, jego

71 Lingwistycznie i tematycznie jednak, przez słowo ,ubranie”, wiersz 5 (śimlat) łączy się jedynie z wierszami 3 (léśimlātô) i 12 (kěsûtekā).

72 Zaniechanie tego obowiązku, w związku z kwestią rozwodów, zarzuca powygnaniowej społeczności również prorok Malachiasz (por. M1 2,10-16, zwł. 15), traktując takie zachowanie jako złamanie przymierza z Bogiem. 
pełnego, być może nawet podstawowego znaczenia. Przemyślany dobór słów (zwłaszcza wybór zwrotu kelî-geber) każe sądzić, że prawodawcy chodziło o szczególne podkreślenie „męskości” (słowo geber) i tego, co w sposób szczególny przynależy do tej „męskości” (słowo kelî). Może to być ogólnie rozumiane ubranie, ale też broń lub inne „męskie” wyposażenie. Z drugiej strony zwrot śimlat ’iššāh, który opisuje wierzchnie odzienie kobiety, również ma na uwadze ogólnie rozumiany zakaz przebierania się za kobiety. W obu sformułowaniach chodzi zatem o „ochronę specyfiki męskości”, o zakaz naruszania granic $\mathrm{w}$ tym zakresie, obowiązujących w patriarchalnym społeczeństwie, a nie o zakaz przebierania się w ogóle. Innymi słowy, kobiety nie powinny sięgać po to, co specyficznie męskie (maskulinizacja), ani tym bardziej mężczyźni nie powinni sami dokonywać swojej feminizacji, przywdziewając kobiece stroje.

\section{ks. Janusz LEMAŃSKI}

Słowa kluczowe: transwestytyzm; męskość; Księga Powtórzonego Prawa; płeć; prokreacja

Keywords: Cross-Dressing; Masculinity; The Book of Deuteronomy; sexuality; pro-creation

\section{(Post-)Deuteronomistic Prohibition of Transvestitism (Deut 22:5): The Question of its Proper Meaning and Motivations}

\section{Summary}

Deut 22:5 is the only prohibition of transvestitism in the Bible and its cultural environment. The context in which it appears suggests that it was inserted secondarily, in the period after the Babylonian Exile. This view narrows down various speculations concerning the original Sitz im Leben of this precept, and it leads one to understand it primarily within the framework of the canonical shape of the whole Pentateuch. Accordingly, this regulation mainly refers to the rule of the bisexual division of human nature (Gen 1-2), the rule of preserving the order of creation (not mixing species; Lev 19:19; Deut 22:9-11), as well as the preservation of the procreative force, here mainly related to masculinity (Gen 5:1-3; cf. 1:28; 9:1.7). 


\section{Bibliografia}

Attridge H. W., Oden R. A., The Syrian Goddess (De Dea Syria). Attributed to Lucian, Society of Biblical Literature. Texts and Translations 9, Scholars, Missoula 1976.

Beyse K. M., kelî, w: TDOT, t. 7, Eerdmans, Grand Rapids 1995, s. 169-175.

Biddle M. E., Deuteronomy, Smith\&Helwys, Macon 2003.

Black J., Green A. (red.), Słownik mitologii Mezopotamii, Księżnica, Katowice 1998.

Bratsioti N. P., 'îš, w: Theological Dictionary of the Old Testament, t. 1, Eerdmans, Grand Rapids 1977, s. 222-235 (TDOT).

Braulik G., Deuteronomium II16,18 - 34,12, NEB, Echter Verlag, Würzburg 1992.

Brettler Zvi M., Gender in the Bible, w: A. Berlin, M. Zvi Brettler (red.), Jewish Study Bible, Oxford University Press, New York 2014, s. 2177-2184.

Brettler Zvi M., Happy is the man, who fills his quiver with them" (Ps 127,5):

Construction of Masculinities in the Psalms, w: I. Zsolnay (red.), Being a Man: Negatiating Ancient Constructs of Masculinity, Studies in the History of the Ancient Near East, Routledge, London 2017, s. 198-203.

Carmichael C. M., The Law of Deuteronomy, Cornell University Press, Ithaca 1974.

Christensen D. L., Deuteronomy 21,10 - 34,12, WBC 6B, Thomas Nelson Publishing, Nashville 2002.

Clines D. J. A. (red.), The Dictionary of Classical Hebrew, t. 1-8, Academic Press, Sheffield 1993-2011.

Craigie P. C., The Book of Deuteronomy, NICOT, Eerdmans, Grand Rapids 1976.

Crouch C. L., The Making of Israel: Cultural Diversity in the Southern Levant, Brill, Leiden-Boston 2014.

Doerfler M. E., Coming Apart at the Seams: Cross-dressing Masculinity, and the Social Body in Late Antiquity, w: A. Batten, C. Daniel-Hughes, K. Upson-Saia (red.), Dressing Judeans and Christians in Antiquity, VT: Ashgate, Burlington 2014, s. 37-54.

Drijvers H. J. W., Atargatis, w: K. van der Toorn i in. (red.), Dictionary of Deities and Demons in the Bible, Brill, Leiden-Boston-Köln 1999, s. 114-116.

Driver S. R., A Critical and Exegetical Commentary on Deuteronomy, ICC, T\&T Clark, Edinburg 1895.

Filon Alexandryjski, Pisma, tłum. L. Joachimowicz, Instytut Wydawniczy Pax, Warszawa 1986.

Flawiusz Józef, Dawne dzieje Izraela, cz. 1, tłum. Z. Kubiak, J. Radożycki, Oficyna Wydawnicza Rytm, Warszawa 1997. 
Fox N. S., Gender Transformation and Transgression: Contextualizing the Prohibition of Cross-Dressing in Deuteronomy 22:5, w: N. S. Fox, D. A. Glatt-Gilad, M. J. Williams (red.), Mishneh Todah. Studies in Deuteronomy and Its Cultural Environment. Fs. J. H. Tigay, Eisenbrauns, Winona Lake 2009, s. 49-71.

Frymer-Kensky T., Law and Philosophy: The Case of Sex in the Bible, Semeia 45/1989, s. 89-102.

Gaster Th. H., Myth, Legend, and Custom in the Old Testament, Harper \& Row, New York 1969.

Goldingay J., Old Testament Theology, t. 3: Israel's Life, IPV Academic Dovners, Grove 2009.

Gordon C. H., A Note on the Tenth Commandment, Journal of Bible and Religion 31/1963, s. 208-209.

Groneberg B., Die sumerisch-akkadische Inanna/Ištar: Hermaphroditas? Die Welt des Orients 17/1986, s. 25-46.

Hallo W. W., Biblical Abominations and Sumerian Taboos, Eisenbrauns 1985, s. 21-40.

Hamilton V. P., gebîrâ, w: NIDOTTE, t. 1, Paternoster Press, London 1997, s. $800-802$.

Harland P. J., Menswear and Womenswear: A Study of Deuteronomy 22:5, Expository Times 110/1998-1999, s. 73-76.

Harris R., Inanna-Istar as Paradox and a Coincidence of Opposites, History of Religion 30/1991, s. 261-278; toż, w: tenże (red.), Gender and Aging in Mesopotamia: The Gilgamesh Epic and Other Ancient Literature, University of Oklahoma Press, Norman 2000, s. 158-171.

Helck W., Betrachtungen zur Grossen Göttin und der ihn verbundenen Gottheiten, Religion und Kultur der alten Mittelmeerwelt in Parallelforschungen, Oldenbourg, München-Wien 1971.

Hölscher G., Komposition und Ursprungs der Deuteronomiums, Zeitschrift für die alttestamentlische Wissenschaft 40/1922, s. 161-225.

Hoffner H. A. jr., Symbols for Masculinity and Femininity: Their Use in Ancient Near Eastern Pathetic Magic Rituals, Journal of Biblical Literature 85/1966, s. 326-334.

Houtman C., Another Look at Forbidden Mixtures, Vetus Testamentum 34/1984, s. $226-228$.

Jurewicz O. (oprac.), Słownik grecko-polski, Wydawnictwo Szkolne PWN, Warszawa 2001.

Kaufman S. A., The Structure of the Deuteronomic Law, Maarav 12/1978-1979, s. $105-158$. 
Kletter R., Pots and Polities: Material Remaine of Late Iron Age Judah in Relation to Its Political Border, Bulletin of the American Schools of Oriental Research 34/1999, s. 19-54, 381-385.

Koehler L., Baumgartner W., Stamm J. J. (red.), Wielki stownik hebrajsko-polski i aramejsko-polski Starego Testamentu, t. 1-2, „Vocatio”, Warszawa 2008 ( KBL).

Kosmala H., gabar, w: TDOT, t. 2, Eerdmans, Grand Rapids 1977, s. 367-382.

Lambert W. G., Babylonian Wisdom Literature, Clarendon, Oxford 1960.

Lemański J., Księga Rodzaju rozdziały 1 - 11, NKB.ST I/1, Św. Paweł, Częstochowa 2013.

Lemański J., Księga Rodzaju rozdziały 11,27 - 36,43, NKB.ST I/1, Św. Paweł Częstochowa 2014.

Licht H., Sexual Life in Ancient Greece, tłum. J. H. Freese, Constable, London 1994 (oryg. niem. z 1931).

Liebman T., The Jewish Exegetical History of Deuteronomy 22:5: Required Gender Separation or Prohibited Cross-Dressing? Masters Thesis, Departament of Jewish Studies, McGill University, Montreal 2002.

Lipka H., The Prohibition of Cross-Dressing. What does Deuteronomy 22: 5 Prohibit and Why? hetorach.com (dostęp: 10 VI 2019).

Lundbom J. R., Deuteronomy. A Commentary, Eerdmans, Cambridge 2013.

Lust J., Eynikel E., Hauspie K. (red.), A Greek-English Lexicon of the Septuagint, t. 1-2, Deutsche Bibelgesellschaft, Stuttgart 1996.

Łach S., Ksiega Powtórzonego Prawa, PŚST II-3, Pallotinum, Poznań-Warszawa 1971.

Mayes A. D. H., Deuteronomy, NCBC, Eerdmans, Grand Rapids1981².

Merrill E. H., Deuteronomy, NAC 4, B\&H Publishing Group, Nashville 1994.

Meyer R., Donner H. (red.), Gesenius Hebräisches und aramäisches Handwöwerterbuch über das Alte Testament, t. 1-7, Springer Verlag, Berlin 1987-2012 $\left(\mathrm{Ges}^{18}\right)$.

Miller P. D., Deuteronomy, John Knox, Louisville 1990, s. 162.

Nelson R. D., Deuteronomy, OTL, John Knox Press, Louisville-London 2002.

Nielsen E., Deuteronomium, HAT 1/6, Mohr-Siebeck, Tübingen 1995.

Otto E., Deuteronomium 12,1 - 23,15, HThKAT, Herder, Freiburg-Basel-Wien 2016.

Packer J. I., Tenney M. C. (red.), Stownik tła Biblii, tłum. Z. Kościuk, „Vocatio”, Warszawa 2007.

Paganini S., Deuteronomium, I libri Biblici, Primo Testamento, Paoline, Milano 2011.

Penna A., Deteronomio, Manetti, Torino-Roma 1976. 
Pritchard J. B. (red.), Ancient Near Eastern Texts Relating to the Old Testament, University Press, Princeton $1969^{3}\left(\right.$ ANET $\left.^{3}\right)$.

Pryke L. M., Ishtar: Gods and Heroes of Ancient World, Routledge, London-New York 2017).

Rad von G., Deuteronomio, tłum. A. dal Bianco, Paidea Editrice, Brescia 1979 Brescia: (oryg. niem. 1964).

Rad von, G., Teologia Starego Testamentu, tłum. B. Widła, Instytut Wydawniczy Pax, Warszawa 1986.

Rodd C. S., Glimpses of a Strange Land. Studies in Old Testament Ethics, T\&T Clark, Edinburg 2001.

Römer W. H. Ph., Randbemerkungen zur Travestie von Deut. 22.5, w: M. Heerm van Voss i in. (red.), Travestie in the World of the Old Testament, Studia Semitica Neerlandica 16, LVan Gorcum, Assen 1974, s. 217-222.

Rofé A., The Arangement of the Laws in Deteronomy, w: tenże, Deuteronomy. Issues and Interpretation, T\&T Clark, London-New York 2002, s. 55-77.

Roscoe W., Priest of the Goodess: Gender Transgression in Ancient Religion, History of Religion 35 (1996) 213-217.

Slawik J. i I., Homoseksualizm problemem Kościoła? Rocznik Teologiczny 52/2010, s. 9-69.

Steuernagel C., Das Deuteronomium übersetzt und erklärt, HK I 3/1, Vandenhoeck\& Ruprecht, Göttingen $1923^{2}$.

Tigay J. H., Deuteronomy, JPS Torah Commentary, Philadelphia Jewish Publication Society 1996.

Tronina A., Eposy ugaryckie o Kerecie i Akhacie, w: A. Paciorek (red.), Scripturae Lumen. Biblia i jej oddziatywanie, t. 1: Ewangelia o Królestwie, Wydawnictwo KUL, Lublin 2009, s. 563-621.

Vedeler H. T., Reconstructing Meaning in Deuteronomy 22:5: Gender, Society, and Transvestitism in Israel and the Ancient Near East, Journal of Biblical Literature 127/2008, s. 459-476.

Walton J. H., Walton J. H., The Lost World of the Torah: Law as Covenant in Ancient Context, IVP Academic, Downer Grove 2019.

Weinfeld M., Deuteronomy and Deuteronomic School, Clarendon, Oxford 1972.

Weippert H., Kleidung, w: M. Görg, B. Lang (red.), Neues Bibel-Lexikon, t. 2, Benziger, Zürich-Düsseldorf 1995, s. 495-499.

Wenham G. J., The Old Testament Attitude to Homosexuality, Expository Times 102/1990-1991, s. 259-363. 